\title{
Cattle Behavior on a South Florida Range
}

G.W. TANNER, L.D. SANDOVAL, AND F.G. MARTIN

\begin{abstract}
Grazing, resting, defecating, and urinating behaviors of cattle (Zebu-European cross breeds) were monitored seasonally on a south Florida range from November 1980 through August 1981. Individual animals were continuously during daylight hours in a pasture containing 4 plant communities. Distributions of time spent grazing and resting and counted occurrences of excretion were significantly different among the 4 seasons. Grazing time in the 4 plant communities was not in proportion to their size. Cattle grazed more in those communities that had the best quality of forage available. Cattle grazed more in the freshwater marsh during fall but spent more time in the ecotone during spring and summer. Shade was not a requisite for resting sites, even during the warmest days. Excretion activities were more closely associated with grazing than resting.
\end{abstract}

South Florida range pastures usually contain several communities. The flatwood community usually occupies the majority of landscape, but freshwater marshes are common and produce high levels of native forage which is comparatively high in nutritive value (Yarlett 1974). Since freshwater marshes provide good quality pasturage at little or no cost, many ranchers depend upon marsh grazing in their operations (Gatewood and Cornwell 1976).

Chronic overuse of marsh pastures may lead to water pollution problems due to the congregating of animals within the marsh (McCaffrey et al. 1976). The proportion of time that cattle spend in marsh communities, given the opportunity to graze uplands, has not been documented. This study was designed to monitor seasonal cattle activities within a pasture containing freshwater marsh and flatwoods communities typical of south-Florida range.

\section{Materials and Methods}

Approximately 100 ha of Armstrong Slough on the El Maximo Ranch, Latt Maxey Corp., Osceola County, Fla., was fenced to include a portion of freshwater marsh along with the surrounding flatwoods community. The marsh had been ditched in the past to facilitate surface water drainage into the Kissimmee River, located about $3.2 \mathrm{~km}$ to the south.

Soil series within the marsh were mostly Delray and Pompano sands; pockets of Samsula muck were present in the marsh (USDA 1979). Soils of the adjacent flatwoods were Smyrna, Myakka, and Immokalee sands. Climate of the area is characterized by long, warm, humid summers and mild, dry winters. Average (1965 to 1981) annual rainfall was $112 \mathrm{~cm}$. However, during the study period (November 1980 to August 1981) only $50 \mathrm{~cm}$ of rainfall was recorded. Most of this precipitation occurred in November (11.0 $\mathrm{cm})$, February $(6.5 \mathrm{~cm})$, March $(6.0 \mathrm{~cm})$, and June $(19.5 \mathrm{~cm})$. None occurred in April, May, July, or August, although records indicate late summer to be relatively wet. Freezing temperatures are infrequent and seldom occur on 2 or 3 nights in succession. During the hottest months, July and August, maximum air temperatures

\footnotetext{
Authors are assistant professor, School of Forest Resources and Conservation, University of Florida, Gainesville; biologist, Bureau of Forest Development, Parks, Range and Wildlife Division, Diliman, Quezon City, Phillipines; and associate statistician. Department of Statistics. University of Florida. Gainesville.

This article is Florida Agriculture Experiment Station Series Article 4854.

Manuscript received January 19, 1983.
}

average about $34^{\circ} \mathrm{C}$, while minimum temperatures average abut $22^{\circ} \mathrm{C}$ (USDA 1979).

Four plant communities delineated in the study pasture included marsh, flatwood, the ecotone between marsh and flatwoods and a man-made canal bank. The marsh community covered approximately $26 \%$ of the total area. Plant species of the marsh community included maidencane (Panicum hemitomon), cutgrass (Leersia hexandra), torpedograss (Panicum repens), soft rush (Juncus effusus) and pickerelweed (Pontederia cordata). The ecotone community, inundated only during severe rain events, occupied about $16 \%$ of the pasture. Its major plant species were carpetgrasses (Axonopis affinis and $A$. furcata), bahiagrass (Paspalum notatum) and beakrushes ( $R$ hynchospora sp.). The canal bank was the smallest community ( $7 \%$ of the area) and was formed as the result of ditching activities within the marsh community. It was about 0.5 to $1.5 \mathrm{~m}$ higher in elevation than the adjacent marsh community and had been seeded to bahiagrass to reduce potential erosion. Carpetgrasses and common bermudagrass (Cynodon dactylon) also were common.

Nearly half of the study pasture $(48 \%)$ was occupied by the flatwoods community. Scattered mottes of southern waxmyrtle (Myrica cerifera) and live oak (Quercus virginiana) and scattered slash pine (Pinus elliottii) within the flatwoods provided the only shade on the pasture. Saw-palmetto (Serenoa repens) and gallberry (Ilex glabra) were the dominant shrubs. Herbaceous vegetation in the flatwoods was dominated by pineland threeawn (Aristida stricta), chalky bluestem (Andropogon capillipes), broomsedge bluestem (A. virginicus) and several Dicanthelium and beakrush species.

Although the 100-ha study pasture had a perimeter fence, the gates were never closed. Consequently, animal densities within the pasture varied. Goldstein (1982) reported cattle densities in the immediate area to be $0.5 \mathrm{cow} / \mathrm{ha}$ on an annual basis. Horses, sheep, goats, feral pigs, and deer used the pasture in addition to domestic cattle. Cattle utilizing the pasture were of mixed breeds with Brahman traits being dominant.

Seasonal cattle activities were monitored between 8 November to 15 December 1980 (fall), 24 January to 1 March 1981 (winter), 4 April to 15 June 1981 (spring), and 1-15 August 1981 (summer). Within each of the 4 seasons, cattle were observed for 10 days. A continuous observation scheme was employed during each observation day (Johnson-Wallace and Kennedy 1944). On each day 1 cow from the herd using the pasture was arbitrarily selected for monitoring. Each observation day was approximately 10 to $11 \mathrm{hr}$ in length, beginning at about $0700 \mathrm{hrs}$ and ending about 1800 to 1850 hrs. All activities, duration, location by plant community, and time of day were recorded. Activity categories were: grazing, ruminating, walking, standing, lying, drinking, defecating, and urinating. Grazing included grazing while walking and browsing. Ruminating activity included ruminating while lying and standing. Ruminating, standing, and lying activities were combined and considered as resting. Only grazing, resting, defecating, and urinating activities are included here. Cattle using the study pasture were frightened by human confrontation; therefore, observations were made with binoculars from distances of 50 to $100 \mathrm{~m}$. 


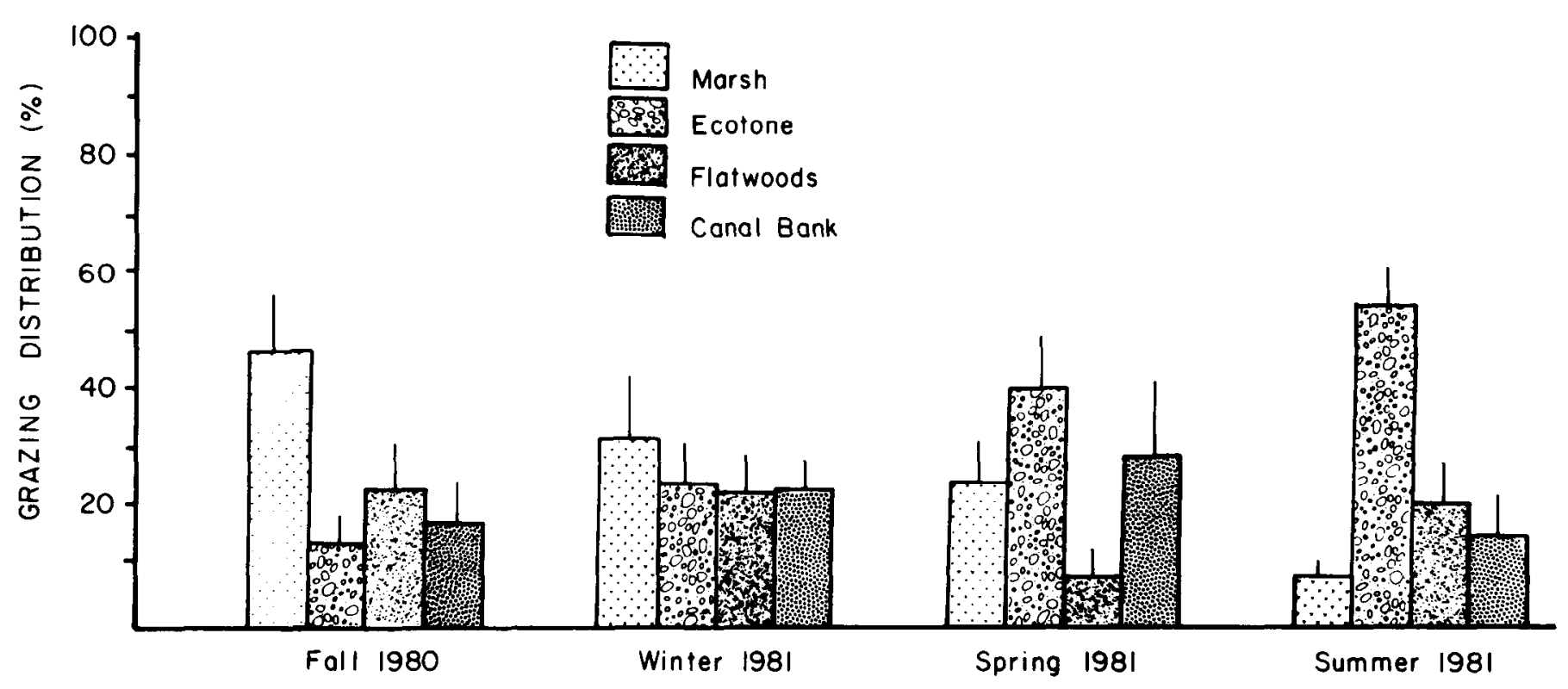

SEASON

Fig. 1. Average seasonal grazing distribution within the major plant communities of Armstrong Slough, Osceola County, Fla. Lines extending from each bar indicate upper regions of S.E. of mean.

The percentage of time spent grazing and resting within the 4 plant communities during 10 days in each of 4 seasons was tested by vector analyses (Watson 1956, Kambacher et al. 1982). Defecation and urination data however, were tested by Chi-square Means were compared two at a time using an ad hoc Least Significant Difference test (Steel and Torrie 1960).

\section{Results and Discussion}

There were significant $(P<0.01)$ differences in seasonal distributions of time spent grazing among the 4 communities (Fig. 1). Mean comparison tests indicated grazing distributions in fall and winter and in winter and spring not to be significantly different, respectively. The summer distribution of grazing activities was significantly different from the other 3 seasons'distributions. During fall 1980 cattle spent a significantly higher amount (48\%) of their time grazing the marsh; use of this community steadily declined to a low of $8 \%$ in summer. The seasonal trend of grazing within the ecotone community, however, was exactly opposite to the marsh, increasing from 13 to $55 \%$ from fall to summer. Grazing was most easily distributed among the 4 communities in winter.

Differential use of the 4 communities for grazing was most closely related to the seasonal characteristics of forage availability and nutritive value within those communities (Table 1). Canal

bank vegetation was not sampled for biomass nor nutritional parameters. In general, range forages in Florida have low digestibility and low protein and mineral content due to poor soil fertility and climatic conditions (Lewis et al. 1982). Maidencane, cutgrass and torpedograss, the dominant grass species within the marsh community, are among the most nutritious native species and highly preferred by cattle when green. The decline in utlization of the marsh community for grazing from fall to summer was a response to cold weather in winter and early spring and flooding in early summer. Cattle do not graze maidencane after frost (R.S. Kalmbacher, personal communication $)^{1}$, and the flooded condition decreased the availability of marsh forage during the summer.

During winter grazing was evenly distributed throughout the 4 plant communities (Fig. 1). However, this response may had been due to the scarcity of winter forage throughout the entire pasture (463.4 to $1,055.6 \mathrm{~kg} / \mathrm{ha}$ ). Increased grazing activity within the ecotone community in spring and summer was due to the abundance of carpetgrasses and bahiagrass. These species ranked second in quality to marsh forages (Tanner et al. 1982) but were not

IResearch Agronomist, Ona Agricultural Research Center, Ona, Fla.

Table 1. Mean aerial biomass, IVOMD and crude protein values of plant samples collected within the three major plant communities on Armstrong Slough, Osceola County, Florida. IVOMD and crude protein data previously were reported in Tanner et al. (1982).

\begin{tabular}{|c|c|c|c|c|c|c|c|c|c|}
\hline \multicolumn{10}{|c|}{ Forage charactcristic } \\
\hline & \multicolumn{3}{|c|}{ Aerial biomass (kg/ha) } & \multicolumn{3}{|c|}{ IVOMD (\%) } & \multicolumn{3}{|c|}{ Crude protein (\%) } \\
\hline & Upland & Ecotone & Marsh & Upland & Ecotone & Marsh & Upland & Ecotonc & Marsh \\
\hline $\begin{array}{l}\text { Fall } \\
\text { Winter } \\
\text { Spring } \\
\text { Summer }\end{array}$ & $\begin{array}{l}2247.8_{a}{ }^{d} \\
1055.6_{c}{ }^{d} \\
1023.4_{a}{ }^{e} \\
1642.7_{b}{ }^{d e}\end{array}$ & $\begin{array}{r}1472.3_{\mathrm{a}^{\mathrm{d}}} \\
506.3_{\mathrm{c}}{ }^{\mathrm{e}} \\
869.8_{\mathrm{bc}} \mathrm{e}^{\mathrm{e}} \\
1205.5_{\mathrm{ab}}\end{array}$ & $\begin{array}{r}2266.4 \mathrm{a}^{\mathrm{d}} \\
463.4 \mathrm{~b}^{\circ}{ }^{\circ} \\
1928.5_{\mathrm{a}}{ }^{\mathrm{d}} \\
2357.6_{\mathrm{a}}{ }^{\mathrm{d}}\end{array}$ & $\begin{array}{l}26.3_{b}{ }^{e} \\
31.8_{b}{ }^{d} \\
36.3_{a}{ }^{d} \\
31.4_{b}{ }^{e}\end{array}$ & $\begin{array}{l}34.5_{\mathrm{ab}} \mathrm{d}^{\mathrm{d}} \\
28.7_{\mathrm{b}}^{\mathrm{d}} \\
36.4_{\mathrm{a}}^{\mathrm{d}} \\
30.9_{\mathrm{b}} \mathrm{d}^{\mathrm{d}}\end{array}$ & $\begin{array}{l}26.4_{\mathrm{ab}}^{\mathrm{e}} \\
31.5_{\mathrm{a}}^{\mathrm{d}} \\
21.3^{\mathrm{b}} \\
27.9_{\mathrm{a}}^{\mathrm{d}}\end{array}$ & $\begin{array}{l}6.9_{a}^{d} \\
6.8_{a}^{a} \\
6 . a^{a} \\
6.5_{a}\end{array}$ & $\begin{array}{l}8.0^{d} \\
8.5 a^{d} \\
6.9 a^{a} \\
7.7 a^{e}\end{array}$ & $\begin{array}{l}7.9 \mathrm{a}^{\mathrm{d}} \\
9.3 \mathrm{a}^{\mathrm{d}} \\
9.4 \mathrm{a}^{\mathrm{d}} \\
9.4 \mathrm{a}^{\mathrm{d}}\end{array}$ \\
\hline
\end{tabular}

IVOMD = In vitro organic matter digestibility

${ }^{2}$ Mean values within season-forage characteristic combinations followed by the same superscript are not significantly different $(P<0.05)$ among communities. Mean values within plant community-forage characteristic combinations followed by the same subscript are not significantly different $(P<0.05)$ among seasons. 


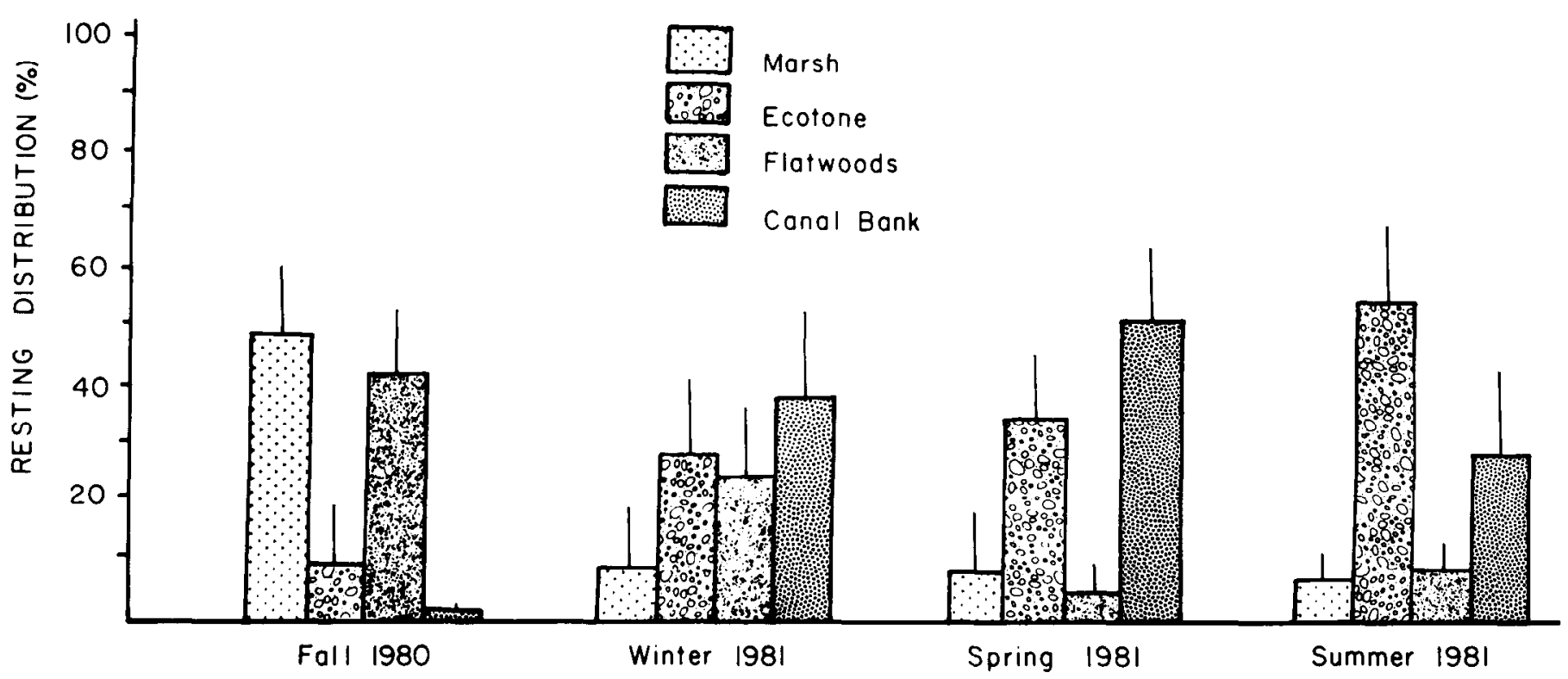

SEASON

Fig. 2. Average seasonal resting distribution within the major plant communities of Armstrong Slough. Osceola County, Fla. Lines extending from each bar indicate upper region of S.E. of mean.

as productive. With the flooded condition in the marsh community in summer, the ecotone community was preferred for grazing during that season.

Although the canal bank and flatwoods communities were the smallest and largest communities in the pasture by size, respectively, cattle did not distribute grazing time in those communities in like proportions. Cattle grazed on he canal bank community ( $7 \%$ of the area) approximately 16 to $30 \%$ of the time, whereas the flatwoods community (48\% of the area) was grazed only 8 to $20 \%$ of the time (Fig. 1). Since the canal bank was seeded to bahiagrass and fertilized for erosion control and carpetgrass also was abundant on the older canal banks, cattle apparently sought out these nutritious forages throughout the year. Conversely, cattle did not seek out the large flatwoods community which was dominated by the lower nutritious pineland threeawn and bluestem species (Lewis et al. 1982) even though relatively higher biomass production existed.

Seasonal distributions of resting among the four communities were significantly $(P<0.01)$ different (Fig. 2). The fall distribution differed significantly from each of the other 3 seasons which were not significantly different from each other. During fall, cattle tended to rest the majority of the time in the marsh (47\%) and flatwoods $(42 \%)$ communities. Resting in these 2 communities declined in the other seasons, while resting in the edge and canal bank communities began to dominate, especially in spring and summer.

Cattle did not seek shade when choosing resting locations, although shade was readily available within the pasture. Cattle rested much of the time in communities without shade (marsh and canal bank) even during the warmer periods of the day. The Zebu-type cattle observed in this study usually are not stressed by high temperatures (Goldson 1963, Musangi 1965). However, during the hottest summer periods, cattle were observed to rest at the ecotone flatwoods interface (Sandoval 1982), which provided trees on the flatwoods and air movement from the ecotone community.

Seasonal frequencies of occurrence for defecation and urination events among the 4 communities are given in Tables 2 and 3 , respectively. Chi-square tests for equal percentage distributions among seasons rejected the null hypothesis for defccation $(P<0.05$,
$X^{2}=44.04$, d.f. $=9$ ), while the null hypothesis for urination and could only be rejected at the $10 \%$ level of significance $\left(X^{2}=15.76\right.$, d.f. =9). A series of ad hoc Least Significant Difference tests indicated that the fall distribution of defecation was significantly

Table 2. Seasonal frequency of occurrence (S.E. of mean) of defecating within the communities of Armstrong Slough, El Maximo Ranch, Latt Maxcy Corp., Osceola County, Florida.

\begin{tabular}{llccc}
\hline & \multicolumn{4}{c}{ Plant Community } \\
\cline { 2 - 4 } Season & Marsh & Ecotone & Canal Bank & Flatwoods \\
\hline Fall 1980 & $58.8(9.0)$ & $5.9(5.2)$ & $14.7(7.0)$ & $20.6(7.8)$ \\
Winter 1981 & $20.0(10.6)$ & $30.0(10.7)$ & $36.7(8.6)$ & $13.3(5.2)$ \\
Spring 1981 & $15.2(5.3)$ & $54.5(7.7)$ & $27.3(9.0)$ & $3.0(2.5)$ \\
Summer 1981 & $10.0(5.8)$ & $\frac{52.5(5.4)}{35.7}$ & $\frac{15.0(7.9)}{23.4}$ & $\frac{22.5(7.4)}{14.9}$ \\
Overall Mean & 26.0 & 35.7 &
\end{tabular}

different $(P<0.05)$ from each of the other 3 seasons, but no other significant differences were detected. The urination data were not examined in any detail. Each community received some form of

Table 3. Seasonal frequency of occurrence (S.E. of mean) of urination within the communities of Armstrong Slough, Osceola County, Florida.

\begin{tabular}{lcccc}
\hline \hline & \multicolumn{4}{c}{ Plant Community } \\
\cline { 2 - 5 } Season & Marsh & Ecotone & Canal Bank & Flatwoods \\
\hline & & & $\%$ & \\
Fall 1980 & $45.0(11.8)$ & $20.0(8.0)$ & $15.0(6.9)$ & $20.0(11.1)$ \\
Winter 1981 & $20.0(10.7)$ & $25.0(10.8)$ & $40.0(11.7)$ & $15.0(6.1)$ \\
Spring 1981 & $23.5(10.9)$ & $47.1(13.0)$ & $29.4(13.2)$ & $0.0(0.0)$ \\
Summer 1981 & $4.2(5.0)$ & $\frac{45.8(12.9)}{25.0(13.2)}$ & $\frac{25.0(8.2)}{27.4}$ & 15.0 \\
Overall Mean & 23.2 & 34.5 & 27.0 & \\
\hline
\end{tabular}

excreta deposition each season; however, the overall average frequencies of occurrence for defecation and urination were greatest 
in the ecotone community, $35.7 \%$ and $34.5 \%$, respectively. Sandoval (1982) reported that both forms of excretion by cattle were most closely correlated $(P<0.001, r=0.23$ for defecation and $P$ $0.001, r=0.22$ for urination) with grazing activity. Excreta densities often are higher in areas where cattle congregate such as at bedding grounds (Hafez et al. 1969) or around watering locations (Shaw and Dodd 1979). However, in this study cattle did not congregate to any large degree during the day as water was available throughout most of the study pasture and shaded resting areas apparently were not sought.

\section{Management Implications}

Cattle will selectively graze marshes when forages are green and available. Therefore, these areas should be used prior to the first freeze. Mineral and supplemental feeding stations and water sources should be located or regulated to improve grazing distribution.

Since cattle will deposit excreta within the marshes as well as in their immediate vicinity, natural hydrologic fluctuations should allow the vegetation and microorganisms of the marsh an opportunity to absorb the added nutrients. Rapid drainage will increase the possibility for off-site pollution. Water control structures should be installed in order to retain water during peak runoff periods in large marshes that have been ditched.

\section{Literature Cited}

Gatewood, S.E., and G.W. Cornwell. 1976. An analysis of cattle ranching in the Kissimmee River Basin. Donald Patton (ed.). Prepared for Division of State Planning by Eco-Impact, Inc., Gainesville, Fla.

Goldson, J.R. 1963. Observations on the grazing behavior of grade dairy cattle in a tropical climate. E. Afr. Agr. Forest. J. 29:72-77.

Goldstein, A.L. 1982. Effects of agricultural land uses on quality of runoff, p. 77-96. In: Progress in wetland utilization and management, P.M. McCaffrey and S.E. Gatewood (eds.). Proc. Symp. sponsored by the Coordinating Council on the Restoration of the Kissimmee River Valley and the Taylor Creek-Nubbin Slough Basin, Orlando, Fla.
Hafez, E.S.E., M.W.Schein, and R. Eubank. 1969. The behavior of cattle, p. 235-295. In: The behavior of domestic animals, E.S.E. Hafez (ed.). Williams and Wilkins Co. Baltimore, Md.

Johnston-Wallace, D.E., and K. Kennedy. 1944. Grazing management practices and their relationship to the behavior of grazing habits of cattle. J. Agr. Sci. 34:190-195.

Kalmbacher, R.S., K.R. Long, M.K. Johnson, and F.G. Martin. 1982. Botanical composition of the diets of esophageal fistulated steers grazing south Florida rangeland. J. Range Manage. (in review).

Lewis, C.E., H.E. Grelen, and G.E. Probasco. 1982. Prescribed burning in southern forest and rangeland improves forage and its use. South J. of App. for. 6:19-24.

McCaffrey, P.M., W.W. Hinkley, R.A. MacGill, and G.D. Cherr. 1976. Report of investigations in the Kissimmee River - Lake Okeechobee watershed. Florida Dep. of Environ. Reg. Tech. Sev. 2:2-610.

Musangi, R.S. 1965. Feed intake studies in ruminants. II. The grazing behavior of Friesian and Nganda steers on tropical pasture. Afr. Soils 10:321-329.

Sandoval, L.D. 1982. Cattle activities on a hydric rangeland. M.S. Thesis, Univ. Florida, Gainesville.

Shaw, R.B., and J.D. Dodd. 1979. Cattle activities and preference following strip application of herbicide. J. Range Manage. 32:449-452.

Steel, R.G.D., and J.H. Torrie. 1960. Principles and procedures of statistics. McGraw-Hill Book Co., Inc., New York.

Tanner, G.W., W.S. Terry, and L.L. Yarlett. 1982. Vegetation dynamics of three freshwater marshes within the Kissimmee River Valley. Final Report for contract DSR 80248je-3. Coordinating Council on the Restoration of the Kissimmee River Valley and Taylor Creek-Nubbin Slough Basin, Tallahassee, Fla.

USDA. 1979. Soil survey of the Osceola County area, Florida. U.S. Soil Cons. Serv.

Watson, G.S. 1956. Analysis of dispersion on a sphere. Monthly notices, Royal Abstr. Soc: Geophysic Suppls. 7:153-159.

Yarlett, L.L. 1974. Marsh range p. 24-26. In: Range Resources of the South. Georgia Agr. Exp. Sta. Bull. N.S. 9.

\title{
Announcing the 1985 Annual Meeting of the Society for Range Management:
}

\author{
Hotel Utah \\ Salt Lake City, Utah \\ February $11-14,1985$
}

You are invited to join the expected 1,500 range professionals who will gather in Salt Lake City, Utah, at the Hotel Utah for the 1985 Annual Meeting of the Society for Range Management. February 11 - 14, 1985. 